\title{
New ion-chromatography method for detection of chlorite, chlorate, and bromate in drinking water
}

https://doi.org/10.21698/rjeec.2020.207

\author{
Proceedings Paper
}

\author{
IULIANA PAUN, VASILE ION IANCU, FLORENTINA LAURA CHIRIAC* ${ }^{*}$ NICOLETA \\ VASILACHE, FLORINELA PIRVU, MARCELA NICULESCU, TOMA GALAON
}

National Research and Development Institute for Industrial Ecology - ECOIND, 71-73 Drumul Podu Dambovitei, 060652, Bucharest, Romania

*Corresponding author (e-mail): laura.badea88@yahoo.com

\begin{abstract}
A direct ion chromatographic method for the determination of chlorite, chlorate, and bromate in the presence of fluoride, chloride, nitrate, nitrite, and bromide in treated drinking waters was described. Separation of target analytes was achieved using an AS19-HC analytical column (250 mm 4 mm), AG 19$\mathrm{HC}$ guard column (50 $\mathrm{mm} \times 4 \mathrm{~mm}$ ), and $\mathrm{KOH} 25 \mathrm{mmol} / \mathrm{L}$ as mobile phase. Inorganic analytes were eluted using a flow rate of $1 \mathrm{~mL} / \mathrm{min}$. The column temperature was set up and maintained at $30^{\circ} \mathrm{C}$. The analyte ions were quantified using a suppressed conductivity detector.
\end{abstract}

Keywords: chlorite, chlorate, bromate, ion chromatography, drinking water

\section{INTRODUCTION}

Drinking water is obtained by raw water disinfection treatments (surface water and groundwater). The most common disinfectants for drinking water are chlorine, chloramines, ozone, and chlorine dioxide. During the disinfection procedure, due to the existence of some organic matter or halides (mainly bromide) in the raw water, inorganic (chlorates, chlorites, and bromates) and organic (especially trihalomethanes) disinfection by-products may occur [1]. Chlorite and chlorate are formed when chlorine dioxide is used to disinfect raw water. Also, chlorate is formed in hypochlorite treated water and it is the result of a complex interaction between ozone and chlorine ion in aqueous solution [2]. Bromate is produced when raw water is treated with ozone if contains bromide anion [3].

International regulations and guidelines also defined maximum concentrations allowed for chlorite, chlorate, and bromate in drinking water. The maximum concentration of chlorate and chlorite have been limited at $0.7 \mathrm{mg} / \mathrm{L}$ by many organizations such as World Health Organization [4], Iranian national standard [5], Japanese standard [6], and Chinese standard [7] while in Canadian guidelines the maximum allowed limit for both chlorate and chlorite anion concentrations is $1 \mathrm{mg} / \mathrm{L}$ [8]. In the United States and Australia, only the chlorite concentration is limited to $1 \mathrm{mg} / \mathrm{L}$ [9] and 0.8 $\mathrm{mg} / \mathrm{L}$ respectively [10].

Bromate, a possible human carcinogen, is regulated at $10 \mu \mathrm{g} / \mathrm{L}$ in many countries around the world.

World Health Organization has estimated that 2 $\mu \mathrm{g} / \mathrm{L}$ bromate in drinking water poses a lifetime cancer risk of 1 in 10,000 [11].

Considerable efforts have focused on the development of new ion chromatographic methods for determining the concentrations of inorganic disinfection by-products (chlorate, chlorite and bromate) in drinking water to meet current limitations from environmental legislation. Ion chromatography with suppressed conductivity detector is an efficient technique for the simultaneous determination of chlorite, chlorate, and bromate ions in the presence of common inorganic anions in drinking water. Several analytical methods have been developed for the determination of these disinfection by-products (chlorate, chlorite, and bromate) using ion chromatography with a conductivity detector and UV detector. The columns, mobile phases, and suppressor/detectors are presented in Table 1. 
Table 1. The columns, mobile phases, and suppressors/detectors used in different ion chromatographic methods for determination of chlorate, chlorite, and bromate

\begin{tabular}{|c|c|c|c|}
\hline Column & Mobile Phase (mM) & Suppressor/ Detector & Reference \\
\hline Ion Pac AS23 /Guard AG23 & $\mathrm{Na}_{2} \mathrm{CO}_{3}: \mathrm{NaHCO}_{3}=4.2: 1$ & $\begin{array}{l}\text { Suppressed conductivity Supp } 5 \text { (4 } \\
\text { x } 250 \mathrm{~mm} \text { ) } \\
\text { Conductivity detector model } 732,\end{array}$ & {$[1]$} \\
\hline $\begin{array}{l}\text { Ion Pac AS9-HC analytical } \\
\text { column }(250 \mathrm{~mm} \times 4 \mathrm{~mm} \\
\text { I.D. }), \text { AG9-HC guard column } \\
(50 \mathrm{~mm} \times 4 \mathrm{~mm} \text { I.D. })\end{array}$ & $8.0 \mathrm{mmol} / \mathrm{L} \mathrm{Na}_{2} \mathrm{CO}_{3}$ & $\begin{array}{l}\text { Suppressed conductivity, ASRS- } \\
\text { ULTRA auto-suppression with } \\
\text { external water mode, } 80 \mathrm{~mA} \\
\text { current, }\end{array}$ & [12] \\
\hline $\begin{array}{l}\text { Ion Pac AS19 (250mmx4 } \\
\text { mm), AG19 (50mmx4 mm) } \\
\text { hydroxide-selective column }\end{array}$ & $\begin{array}{l}\text { 10mM KOH, } \\
0-10 \mathrm{~min}, 10-45 \mathrm{mM} \mathrm{10-25} \mathrm{min}\end{array}$ & $\begin{array}{l}\text { ASRS }{ }^{\mathrm{TM}} \text { ULTRA II operated } 130 \\
\mathrm{~mA} \text {, } \\
\text { Suppressed conductivity }\end{array}$ & {$[13]$} \\
\hline $\begin{array}{l}\text { Carbonate selective Ion Pac } \\
\text { AS9-HC column }\end{array}$ & $9 \mathrm{mM} \mathrm{Na}_{2} \mathrm{CO}_{3}$ & $\begin{array}{l}\text { ASRS ULTRA II operated in the } \\
\text { external water mode }\end{array}$ & {$[13]$} \\
\hline $\begin{array}{l}\text { IonPacAS27 column (250 mm } \\
\text { x } 4 \mathrm{~mm}), \text { AG } 27(50 \mathrm{~mm} \text { x } 4 \\
\mathrm{mm})\end{array}$ & $20 \mathrm{mM} \mathrm{KOH}$ & $\begin{array}{l}\mathrm{AERS}^{\mathrm{TM}} 500(4 \mathrm{~mm}), \text { water, } \\
\text { Conductivity cell, water }\end{array}$ & [14] \\
\hline $\begin{array}{l}\text { IonPac AS9-HC } \\
(250 \mathrm{~mm} 4 \mathrm{~mm}), \mathrm{AG} 9-\mathrm{HC} \\
(50 \mathrm{~mm} \times 4 \mathrm{~mm})\end{array}$ & $9 \mathrm{mM} \mathrm{Na}_{2} \mathrm{CO}_{3}$ & $\begin{array}{l}\mathrm{AERS}^{\mathrm{TM}} 500(4 \mathrm{~mm}), \text { water, } \\
\text { Conductivity cell, water }\end{array}$ & [14] \\
\hline $\begin{array}{l}\text { Ion Pac AS19 (250mmx4 } \\
\text { mm), AG19 (50mmx4 mm) } \\
\text { hydroxide-selective column }\end{array}$ & $\begin{array}{l}\text { 10mM KOH, } \\
0-10 \mathrm{~min}, 10-45 \mathrm{mM} \mathrm{10-25} \mathrm{min}\end{array}$ & $\begin{array}{l}\text { ASRS }{ }^{\mathrm{TM}} \text { ULTRA II operated } 130 \\
\mathrm{~mA}, \\
\text { Suppressed conductivity }\end{array}$ & {$[15]$} \\
\hline $\begin{array}{l}\text { Ion Pac AS19 (250mmx4 } \\
\text { mm), AG19 (50mmx4 mm) }\end{array}$ & $\begin{array}{l}10 \mathrm{mM} \mathrm{KOH}, \\
0-10 \mathrm{~min}, 10-45 \mathrm{mM} \mathrm{10-25} \mathrm{min}\end{array}$ & $\begin{array}{l}\text { ASRS } 300 \text { Anion Regenerating } \\
\text { Suppressor, external water mode } \\
\text { Absorbance detector, } 352 \mathrm{~nm}\end{array}$ & {$[16]$} \\
\hline $\begin{array}{l}\text { IonPac AS9-HC } \\
(250 \mathrm{mmx} 4 \mathrm{~mm}), \mathrm{AG} 9-\mathrm{HC} \\
(50 \mathrm{~mm} \times 4 \mathrm{~mm})\end{array}$ & $9 \mathrm{mM} \mathrm{Na}_{2} \mathrm{CO}_{3}$ & $\begin{array}{l}\text { ASRS-I, external water mode }, 100 \\
\text { mA current, } \\
\text { Suppressed Conductivity detector } \\
\text { CD } 20\end{array}$ & [17] \\
\hline $\begin{array}{l}\text { IonPac AS9-HC } \\
(250 \mathrm{mmx} 4 \mathrm{~mm}), \text { AG9-HC } \\
(50 \mathrm{~mm} \times 4 \mathrm{~mm})\end{array}$ & $9 \mathrm{mM} \mathrm{Na}_{2} \mathrm{CO}_{3}$ & $\begin{array}{l}\text { ASRS-I, external water mode, } 100 \\
\text { mA current, } \\
\text { Suppressed Conductivity detector } \\
\text { CD } 20 \\
\text { PCR suppressor ASRS-I with } \\
\text { sulfuric acid regenerant to acidify } \\
\text { the PCR } \\
\text { Absorbance detector } 10 \mathrm{~mm} \text { cell } \\
\text { path length, set at } 352 \mathrm{~nm} \\
\text { (deuterium lamp) }\end{array}$ & {$[18]$} \\
\hline
\end{tabular}

In this study, a direct ion chromatographic method that allows a quantitative analysis of chlorite, chlorate, and bromate ions in drinking water was established.

\section{MATERIALS AND METHODS}

\section{Chemicals and reagents}

The inorganic disinfection by-products are marketed in the form of sodium salt: sodium bromate, purity $99.5 \%$ and sodium chlorite, purity $80 \%$, (Sigma-Aldrich, Steinheim, Germany) and sodium chlorate, $98 \%$ purity (Merck, Darmstadt, Germany).

The other common anions of drinking water were purchased as standard substances from Merck (Darmstadt, Germany): chloride standard solution $1000 \mathrm{mg} / \mathrm{L}$, fluoride standard solution $1000 \mathrm{mg} / \mathrm{L}$, nitrite standard solution $1000 \mathrm{mg} / \mathrm{L}$, bromide standard solution $1000 \mathrm{mg} / \mathrm{L}$, and nitrate standard solution $1000 \mathrm{mg} / \mathrm{L}$.

Potassium hydroxide used for the mobile phase was acquired from Merck (Darmstadt, Germany). Ultrapure water (DI) used during the experiments was produced in-house. Ultrapure water was solutions preparation. 
Ion Chromatographic equipment

The Thermo Scientific Dionex ICS-5000 Ion Chromatography System is equipped with a conductivity detector. Chromatographic separation was achieved using a Dionex IonPac AS19 (4 x $250 \mathrm{~mm})$ chromatographic column

\section{Method analysis}

Stock solutions of bromate, chlorite, and chlorate were prepared by solving $0.119 \mathrm{~g}$ $\mathrm{NaBrO}_{3}, 0.1337 \mathrm{~g} \mathrm{NaClO}_{3}$, and $0.160 \mathrm{~g} \mathrm{NaClO}_{2}$ in $100 \mathrm{ml}$ ultrapure water. The concentration of each solution was $1000 \mathrm{mg} / \mathrm{L}$.

Intermediate stock solutions of $50 \mathrm{mg} / \mathrm{L}$ of bromate, chlorate, chlorite, chloride, fluoride, nitrate, nitrite, and bromide were prepared from individual solutions. Calibration standard solutions were prepared at concentration ranges from 0.1 to $25 \mathrm{mg} / \mathrm{L}$ from the intermediate stock solution.

The mobile phase used for anions elution was potassium hydroxide. A mobile phase with AG19 (4 x $50 \mathrm{~mm}$ ) guard column. Data collection and processes were conducted using the Thermo Scientific Dionex Chromeleon ${ }^{\mathrm{TM}} 7$ Software.

concentration of $25 \mathrm{mM} \mathrm{KOH}$ was prepared by dissolving $1.4 \mathrm{~g} \mathrm{KOH}$ in $1000 \mathrm{ml}$ ultrapure water. The solution was degassed and filtered through a $0.45 \mu \mathrm{m}$ nylon membrane filter.

The flow rate and temperature were set up at 1 $\mathrm{ml} / \mathrm{min}$ and $30^{\circ} \mathrm{C}$ respectively. The parameters of the chromatographic separation were optimized for performing the best responses for the quantification of each anion.

Figure 1 shows a typical chromatogram of target anions: bromate, chlorate, chlorite, chloride, fluoride, nitrate, nitrite, and bromide standard.

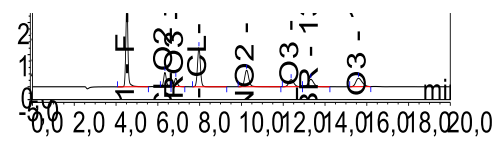

retention times $(\mathrm{min})$

Fig. 1. Chromatogram of anions: bromate $\left(\mathrm{BrO}_{3}\right)$, chlorate $\left(\mathrm{ClO}_{3}\right)$, chlorite $\left(\mathrm{ClO}_{2}\right)$, chloride $\left(\mathrm{Cl}^{-}\right)$, fluoride $\left(\mathrm{F}^{-}\right)$, nitrate $\left(\mathrm{NO}_{3}{ }^{-}\right)$, nitrite $\left(\mathrm{NO}_{2}^{-}\right)$, and bromide $\left(\mathrm{Br}^{-}\right)$.

\section{RESULTS AND DISCUSSION}

The eight anions were separated by $25 \mathrm{mM}$ $\mathrm{KOH}$ eluent and the elution orders are given in
Figure 1. The corresponding retention times are indicated in Table 2.

Table 2. Retention times for interested anions

\begin{tabular}{lc|lc}
\hline Anions & tR $(\mathrm{min})$ & \multicolumn{1}{|c}{ Anions } & tR $(\mathrm{min})$ \\
\hline Fluoride & 4.52 & Nitrite & 10.25 \\
Chlorite & 6.34 & Chlorate & 12.38 \\
Bromate & 6.86 & Bromate & 13.32 \\
Chloride & 7.96 & Nitrate & 15.60 \\
\hline
\end{tabular}

The parameters evaluated in the validation process of the ion chromatographic method for inorganic disinfection by-products detection in the presence of common anions were linearity, repeatability, intermediate precision, detection limit, the limit of determination (quantification), and accuracy. 


\section{Linearity}

The calibration curves were obtained for each domain for all anions as seen in Figure 2. analyte, at the same time, obtaining a linear
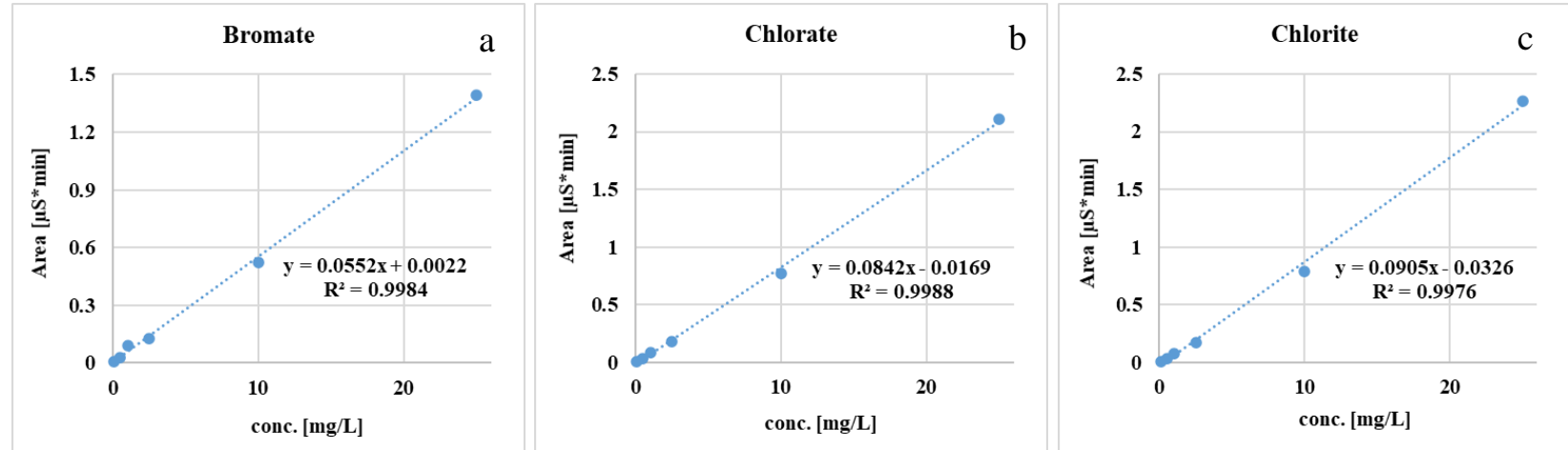

Fig. 2. Calibration curves for bromate (a), chlorate (b) and chlorite (c)

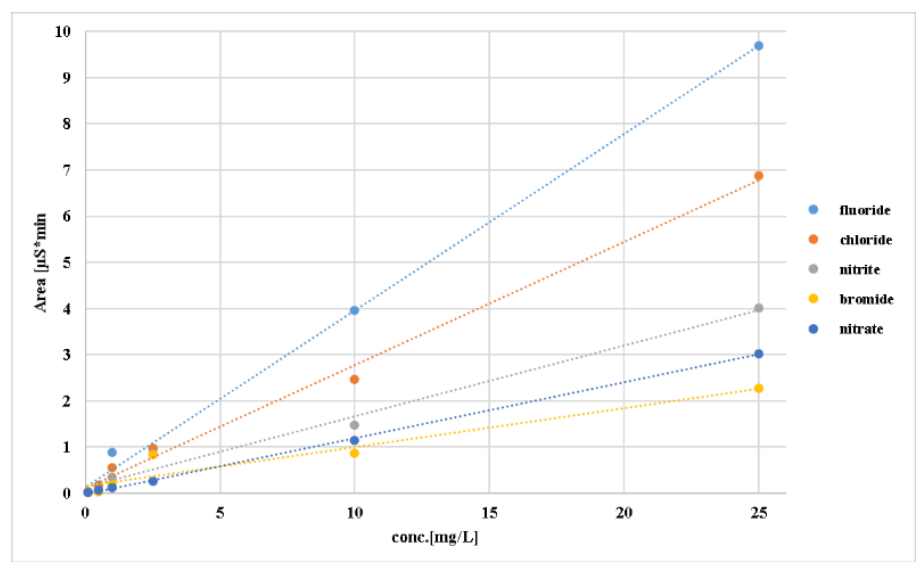

Fig. 3. Calibration curves for the common anions

The working range, correlation coefficients $\left(\mathrm{R}^{2}\right)$, and relative standard deviation values (RSD, \%) are presented in Table 3. As can be seen, the method proved to be precise, the RSD $\%$ values being lower than $10 \%$.

Table 3. Working range (mg/L), correlation coefficient $\left(\mathrm{R}^{2}\right)$, and $\mathrm{RSD}(\%)$ values for the developed method

\begin{tabular}{l|ccc}
\hline \multicolumn{1}{c|}{ Anion } & $\begin{array}{c}\text { Working range } \\
(\mathrm{mg} / \mathrm{L})\end{array}$ & $\begin{array}{c}\text { Correlation } \\
\text { Coefficient }\left(\mathrm{R}^{2}\right)\end{array}$ & RSD $(\%)$ \\
\hline Fluoride & $0.1-25.0$ & 0.9997 & 2.52 \\
Chlorite & $0.1-25.0$ & 0.9965 & 9.01 \\
Bromate & $0.1-25.0$ & 0.9984 & 6.09 \\
Chloride & $0.1-25.0$ & 0.9977 & 7.07 \\
Nitrite & $0.1-25.0$ & 0.9986 & 5.50 \\
Chlorate & $0.1-25.0$ & 0.9984 & 5.98 \\
Bromide & $0.1-25.0$ & 0.9986 & 5.49 \\
Nitrate & $0.1-25.0$ & 0.9992 & 4.17 \\
\hline
\end{tabular}

\section{Detection and quantification limits}

Detection (LOD) and quantification (LOQ) limits for common anions and inorganic disinfection products were determined by measuring the standard solution with a concentration of $0.5 \mathrm{mg} / \mathrm{L}$ each for five times and were calculated at a $95 \%$ confidence level. The LOQ and LOD calculated values are presented in Table 4. 
Table 4. Detection and quantitation limits

\begin{tabular}{lcc|lcc}
\hline \multicolumn{1}{c}{ Anion } & $\begin{array}{c}\mathrm{LOD} \\
(\mathrm{mg} / \mathrm{L})\end{array}$ & $\begin{array}{c}\text { LOQ } \\
(\mathrm{mg} / \mathrm{L})\end{array}$ & Anion & $\begin{array}{c}\text { LOD } \\
(\mathrm{mg} / \mathrm{L})\end{array}$ & $\begin{array}{c}\text { LOQ } \\
(\mathrm{mg} / \mathrm{L})\end{array}$ \\
\hline Fluoride & 0.06 & 0.20 & Nitrite & 0.03 & 0.09 \\
Chlorite & 0.07 & 0.20 & Chlorate & 0.02 & 0.05 \\
Bromate & 0.08 & 0.30 & Bromide & 0.03 & 0.10 \\
Chlorite & 0.08 & 0.30 & Nitrate & 0.02 & 0.06 \\
\hline
\end{tabular}

\section{Method repeatability}

Repeatability gives information on the accuracy of the method when successive measurements of the same sample are performed (same analyst, same sample, same equipment, in a short period).

Five determinations were performed for two solutions of two concentration levels $(0.5 \mathrm{mg} / \mathrm{L}$ and $10 \mathrm{mg} / \mathrm{L}$ ) for each analyte. The obtained results are presented in Table 5 .

Analyzing the results from Table 5, it was observed that among the analyzed inorganic disinfection by-products, the lowest relative standard deviation was obtained for chlorate while the highest relative standard deviation was obtained for bromate, for both concentration levels.

Table 5. Repeatability results

\begin{tabular}{l|cccccccc}
\hline \multicolumn{1}{c|}{ Anion } & $\begin{array}{c}\text { Real } \\
\text { concentration } \\
(\mathrm{mg} / \mathrm{L})\end{array}$ & $\begin{array}{c}\text { Mean } \\
\text { concentration } \\
(\mathrm{mg} / \mathrm{L})\end{array}$ & $\begin{array}{c}\text { SR } \\
(\mathrm{mg} / \mathrm{L})\end{array}$ & Min. & Max. & Median & $\begin{array}{c}\text { RSD } \\
\%\end{array}$ & $\begin{array}{c}\text { Repeatability } \\
(\mathrm{r})\end{array}$ \\
\hline Fluoride & 0.50 & 0.49 & 0.022 & 0.46 & 0.53 & 0.48 & 4.41 & 0.606 \\
Chlorite & 0,50 & 0.49 & 0.024 & 0.45 & 0.52 & 0.48 & 4.97 & 0.678 \\
Bromate & 0.50 & 0.48 & 0.028 & 0.43 & 0.51 & 0.47 & 5.77 & 0.782 \\
Chloride & 0.50 & 0.48 & 0.018 & 0.47 & 0.51 & 0.48 & 3.61 & 0.494 \\
Nitrite & 0.50 & 0.49 & 0.009 & 0.47 & 0.50 & 0.48 & 1.89 & 0.258 \\
Chlorate & 0.50 & 0.47 & 0.005 & 0.47 & 0.48 & 0.47 & 1.07 & 0.142 \\
Bromide & 0.50 & 0.48 & 0.011 & 0.47 & 0.50 & 0.47 & 2.30 & 0.311 \\
Nitrate & 0.50 & 0.48 & 0.006 & 0.47 & 0.49 & 0.48 & 1.23 & 0.166 \\
Fluoride & 10.0 & 9.98 & 0.104 & 9.80 & 10.06 & 9.98 & 1.04 & 0.291 \\
Chlorite & 10.0 & 8.98 & 0.104 & 8.80 & 9.05 & 8.98 & 1.16 & 0.381 \\
Bromate & 10.0 & 9.07 & 0.136 & 8.89 & 9.24 & 9.07 & 1.50 & 0.368 \\
Chloride & 10.0 & 9.09 & 0.131 & 8.87 & 9.22 & 9.09 & 1.45 & 0.317 \\
Nitrite & 10.0 & 9.26 & 0.113 & 9.06 & 9.33 & 9.29 & 1.22 & 0.305 \\
Chlorate & 10.0 & 9.24 & 0.109 & 9.05 & 9.30 & 9.26 & 1.18 & 0.308 \\
Bromide & 10.0 & 9.30 & 0.110 & 9.11 & 9.37 & 9.32 & 1.18 & 0.618 \\
Nitrate & 10.0 & 9.36 & 0.221 & 9.02 & 9.54 & 9.36 & 2.36 & 0.290 \\
\hline
\end{tabular}

\section{Intermediate precision}

Intermediate precision gives information on the variability of the method in reproducibility conditions (same method, same sample, same laboratory, same equipment, but different analysts and a longer time interval).
Five determinations were performed for two consecutive days for a $10 \mathrm{mg} / \mathrm{L}$ standard solution for each anion. The obtained results are given in Table 6.

Table 6. Intermediate precision results

\begin{tabular}{c|cccccccc}
\hline Anion & $\begin{array}{c}\text { Real } \\
\text { concentration } \\
(\mathrm{mg} / \mathrm{L})\end{array}$ & $\begin{array}{c}\text { Mean } \\
\text { concentration } \\
(\mathrm{mg} / \mathrm{L})\end{array}$ & $\begin{array}{c}\text { SR } \\
(\mathrm{mg} / \mathrm{L})\end{array}$ & Min. & Max. & Median & $\begin{array}{c}\text { RSD } \\
(\%)\end{array}$ & $\begin{array}{c}\text { Intermediate } \\
\text { precision } \\
(\mathrm{R})\end{array}$ \\
\hline Fluoride & 10.0 & 9.93 & 0.415 & 9.09 & 10.71 & 10.01 & 4.17 & 1.161 \\
\hline
\end{tabular}




\begin{tabular}{l|cccccccc}
\hline Chlorite & 10.0 & 9.13 & 0.207 & 8.80 & 9.44 & 9.04 & 2.27 & 0.580 \\
Bromate & 10.0 & 9.20 & 0.167 & 8.89 & 9.37 & 9.26 & 1.82 & 0.468 \\
Chloride & 10.0 & 9.28 & 0.326 & 8.87 & 10.11 & 9.24 & 3.51 & 0.912 \\
Nitrite & 10.0 & 9.39 & 0.179 & 9.06 & 9.66 & 9.32 & 1.91 & 0.503 \\
Chlorate & 10.0 & 9.31 & 0.320 & 9.05 & 10.18 & 9.24 & 3.44 & 0.896 \\
Bromide & 10.0 & 9.29 & 0.114 & 9.06 & 9.39 & 9.34 & 1.23 & 0.320 \\
Nitrate & 10.0 & 9.52 & 0.229 & 9.02 & 9.71 & 9.60 & 2.41 & 0.643 \\
\hline
\end{tabular}

The values of relative standard deviations were varied between 1.23 and $4.17 \%$.

\section{Method accuracy}

To determine the method accuracy, two different types of water matrices (tap water and groundwater) were spiked with a known amount of the chlorate, chlorite, and bromate (5 $\mathrm{mg} / \mathrm{L}$ each). For tap water and groundwater containing chlorate, chlorite, and bromate the recoveries ranges were presented in Table 7 . The values of recovery were situated between 79.9 and $81.8 \%$ for chlorite, 81.8 and $84.6 \%$ for bromate, 91.8 and $93 \%$ for chlorate.

Table 7. Recovery values

\begin{tabular}{l|cccccc}
\hline \multirow{2}{*}{ Sample } & \multicolumn{2}{|c}{ Chlorite } & \multicolumn{2}{c}{ Bromate } & \multicolumn{2}{c}{ Chlorate } \\
\cline { 2 - 7 } & $\begin{array}{c}\text { Value } \\
\text { added } \\
(\mathrm{mg} / \mathrm{L})\end{array}$ & $\begin{array}{c}\text { Recovery } \\
(\%)\end{array}$ & $\begin{array}{c}\text { Value } \\
\text { added } \\
(\mathrm{mg} / \mathrm{L})\end{array}$ & $\begin{array}{c}\text { Recovery } \\
(\%)\end{array}$ & $\begin{array}{c}\text { Value } \\
\text { added } \\
(\mathrm{mg} / \mathrm{L})\end{array}$ & $\begin{array}{c}\text { Recovery } \\
(\%)\end{array}$ \\
\hline Tap water 1 & 5 & 80.2 & 5 & 84.4 & 5 & 93.0 \\
Tap water 2 & 5 & 79.8 & 5 & 84.6 & 5 & 92.2 \\
Tap water 3 & 5 & 81.8 & 5 & 81.8 & 5 & 92.2 \\
Ground water 1 & 5 & 80.0 & 5 & 84.2 & 5 & 93.0 \\
Ground water 2 & 5 & 81.2 & 5 & 84.2 & 5 & 91.8 \\
Ground water 3 & 5 & 80.0 & 5 & 84.2 & 5 & 92.6 \\
\hline
\end{tabular}

\section{Application to municipal drinking waters}

The developed method was successfully tested on real water samples. Tap water samples were collected from 45 sampling points from the municipal drinking water distribution system.

\section{CONCLUSIONS}

The direct ion-chromatographic method with a conductivity detector was developed and fully validated in the laboratory. The new IC method was used to determine the inorganic disinfection by-products resulting from chlorination/disinfection of drinking water (chlorate and chlorite) in presence of common water ions (fluoride, chloride, bromide, nitrate, nitrite). The IC method was linear over a large concentration range $(0.1-25 \mathrm{mg} / \mathrm{L})$, with correlation coefficients higher than 0.9965 . The RSD values corresponding to method repeatability were in the range of $1.04 \div 5.77$ $\%$, while the RSD values determined for
Chlorate, chlorite, and bromate concentrations were not determinate in none of the investigated drinking water samples, while the other anions were found to be in normal concentration levels.

intermediate precision were situated between 1.23 and $4.17 \%$. Good recoveries were obtained for each inorganic disinfection byproducts: up to $81.8 \%$ for chlorite, up to 84.6 $\%$ for bromate, and up to $93 \%$ for chlorate. The method quantification limits were situated between 0.05 and $0.3 \mathrm{mg} / \mathrm{L}$. After validation, the IC method was applied to real water samples, without any sample preparation step (separation or concentration).

The results demonstrate that this simple and rapid method can be used to monitor the quality of drinking water subjected to chlorination/disinfection. 


\section{REFERENCES}

[1] DJAM, S., NAJAFI, M., AHMADI, S.H., SHOEIBI, S., J. Environ. Health. Sci, 2020, https://doi.org/10.1007/s40201-020-00486-9.

[2] LEVANOV, A.V., ISAIKIA, O.Y., GASANOVA, R.B., UZHEL, A.S., Chemosphere, 229, 2019, p. 68, https://doi.org 10.1016/j.chemosphere.2019.04.105.

[3] LAKHIAN, V., DICKSON-ANDERSON, S.E., Chemosphere, 255, 2020, p. 1, https://doi.org/10.1016/j.chemosphere.2020.126 864.

[4] Bromate in drinking-water. Background document for preparation of WHO Guidelines for drinking-water quality. Geneva, World Health Organization, 2005 (WHO/SDE/WSH/05.08/78).

[5] Institute of Standard and Industrial Research of Iran ISIRI No. 1053: Drinking waterphysical and chemical specifications $5^{\text {th }}$ Revision. Teheran: ISIRI, 2010.

[6] Revision of drinking water quality standards in Japan, Hiroshi Wakayama, MHLW, Japan http://www.nilim.go.jp/lab/bcg/siryou/tnn/tnn02 64pdf/ks0264011.pdf

[7] GB 5749-2006 Standard for Drinking Water Quality, National Standard of the People's Republic of China, 2007.

[8] Health Canada. Guidelines for Canadian Drinking Water Quality-Summary Table. Water and Air Quality Bureau, Healthy Environments and Consumer Safety Branch, Health Canada, Ottawa, Ontario, 2020.

[9] US Environmental Protection Agency, occurrence assessment for the final stage 2 disinfectants and disinfection by products rule, document No. 815-R-05-011, December, Office of Water (4606-M), EPA 815-R-05-011, 2005.
[10] NHMRC, NRMMC, Australian Drinking Water Guidelines Paper 6 National Water Quality Management Strategy. National Health and Medical Research Council, National Resource Management Ministerial Council, Commonwealth of Australia, Canberra, 2011.

[11] Guidelines for drinking-water quality, World Health Organization, 2003

[12] ZHU, B., ZHONG, Z., YAO, J., J. Chromatogr. A, 1118, 2006, p. 106, https://doi.org/10.1016/j.chroma.2006.01.139.

[13] DE BORDA B.M., ROHRER J. S., POHL C. A., SAINI C., J. Chromatogr. A, 1085, 2005, p. 23, https://doi.org/10.1016/j.chroma.2004.12.050. [14] KIM D., JUNG S., LEE G., YUN S., S., LIM H. S., KIM H., J. Anal. Sci. Technol., 30, no. 2, 2017, p. 57, https://doi.org/10.5806/AST.2017.30.2.57.

[15] De Borda, B., Rohrer, J., Application Note 167, Thermo Fisher Scientific, Sunnyvale, CA, USA, 2016.

[16] De Borda, B., Rohrer, J., Application Note 171, Thermo Fisher Scientific, Sunnyvale, CA, USA, 2016.

[17] Method 317.0 Determination of inorganic oxyhalide disinfection by-products in drinking water using ion chromatography with the addition of a post column reagent for trace bromate analysis, Revision 2.0, EPA 815-B-01001. Technical Support Center, Office of ground water and drinking water, U. S. Environmental Protection Agency, Cincinnati, Ohio, 2001.

[18] Method 326.0 Determination of inorganic oxyhalide disinfection by-products in drinking water using ion chromatography incorporating the addition of a suppressor acidified post column reagent for trace bromate analysis, Revision 1.0, 2002. 